\title{
The Immunological Challenges of Cell Transplantation for the Treatment of Parkinson's Disease
}

\author{
Amanda L. Piquet ${ }^{1}$, Kala Venkiteswaran ${ }^{1,2}$, Neena I. Marupudi ${ }^{1}$, Matthew Berk ${ }^{1,2}$, and \\ Thyagarajan Subramanian ${ }^{1,2}$ \\ ${ }^{1}$ Department of Neurology, The Pennsylvania State University College of Medicine, Hershey, PA \\ ${ }^{2}$ Department of Neural and Behavioral Sciences, The Pennsylvania State University College of \\ Medicine, Hershey, PA
}

\section{Abstract}

Dopaminergic cell transplantation is an experimental therapy for Parkinson's disease (PD). It has many potential theoretical advantages over current treatment strategies such as providing continuous local dopaminergic replenishment, eliminating motor fluctuations and medicationinduced dyskinesias, slowing down disease progression or even reversing disease pathology in the host. Recent studies also show that dopaminergic cell transplants provide long-term neuromodulation in the basal ganglia that simulates the combined effects of oral dopaminergic therapy and surgical therapies like deep brain stimulation, the contemporary therapeutic approach to advanced PD. However, dopaminergic cell transplantation in PD as not been optimized and current experimental techniques have many drawbacks. In published experiments to date of attempted dopaminergic grafting in $\mathrm{PD}$, the major challenges are unacceptable graft-induced dyskinesias or failure of such grafts to exceed the benefits afforded by sham surgery. A deleterious host immune response to the transplant has been implicated as a major putative cause for these adverse outcomes. This article focuses on recent advances in understanding the immunology of the transplantation in PD and possible methods to overcome adverse events such that we could translate cell replacement strategies into viable clinical treatments in the future.

\section{Keywords}

dopamine; nigrostriatal degeneration; central nervous system; immunosuppression; stem cells; retinal pigment epithelial cells

\section{Introduction}

Parkinson's disease (PD) is defined by the classic triad of tremors, rigidity and bradykinesia accompanied by the degeneration of the nigrostriatal dopaminergic pathway. The nigrostriatal dopaminergic neurons located in the substantia nigra pars compacta primarily innervate the caudate nucleus and the putamen (striatum). Minor connections also extend

(C) 2012 Elsevier Inc. All rights reserved.

Corresponding Author: Thyagarajan Subramanian, M.D., Departments of Neurology and Neural and Behavioral Sciences, Penn State University Hershey Medical Center, H037, 500 University Drive, Hershey, PA 17033, 1-717-531-0003 x 283961 phone,

1-717-531-0996 fax, tsubram@yahoo.com.

Publisher's Disclaimer: This is a PDF file of an unedited manuscript that has been accepted for publication. As a service to our customers we are providing this early version of the manuscript. The manuscript will undergo copyediting, typesetting, and review of the resulting proof before it is published in its final citable form. Please note that during the production process errors may be discovered which could affect the content, and all legal disclaimers that apply to the journal pertain. 
into the substantia nigra pars reticulata, subthalamic nucleus, Globus pallidus and into the thalamus. The importance of these extra-striatal dopaminergic connections in PD pathophysiology is much debated currently in the literature. With the degeneration of the neurons in the substantia nigra pars compacta there is a considerable drop in the dopamine levels within the striatum [1]. Oral anti-parkinsonian medications, aimed at replacing dopamine in the brain, sufficiently control the motor disabilities seen in early PD; however, there are several undesirable side effects including drug-induced dyskinesias, "wearing off" phenomenon, motor fluctuations, autonomic disturbances, among others [2-5] that develop in mid to late stage PD with the continued use of anti-PD medications. Increasing doses of dopaminergic medications are often needed as the disease progresses, increasing the prevalence of drug-induced side effects. Moreover, it has become clear that oral medications even when administered in a controlled compliant manner does not provide amelioration of the electrophysiological abnormalities in the basal ganglia associated with nigrostriatal degeneration. Medication resistant symptoms are commonly treated with surgical measures such as deep brain stimulation (DBS)[6]. Although the exact mechanism through which DBS works is not established, there is consensus that it causes neuromodulation by altering the electrophysiological discharge patterns in the basal ganglia and its connections.

Depending on the experience of the surgeon and the health of the patient, the morbidity from these surgical procedures is between $2-26 \%$ [7]. DBS is strictly palliative and does not provide a mechanism to restore the nigrostriatal pathway. It is also increasingly recognized that non-motor manifestations of PD add to the disability in advanced disease that remain resistant to contemporary medical and surgical therapies. Thus, new methods of optimized therapy that do not cause undesirable side-effects associated with currently practiced pharmacotherapy and the morbidities associated with currently practiced surgical therapies are unmet needs in contemporary management of PD.

Continuous dopaminergic stimulation (CDS) afforded via continuous delivery of dopamine or its precursors have been proposed as a mechanism to overcome the undesirable effects of long-term oral dopaminergic therapy $[5,8]$. Experiments performed over 3 decades ago showed that continuous delivery of levodopa intravenously or via the duodenum was capable of providing excellent relief of parkinsonism in mid to advanced PD patients [9, 10]. This method has the potential to avoid the complications of therapy associated with oral medications and avoid the need for surgery in PD. However, the practical translation of such a CDS approach has remained problematic and CDS remains an unattained goal in PD patients clinically either via oral medications or via implanted pumps. In advanced PD patients, the administration of levodopa continuously could decrease motor fluctuations and eliminate disabling dyskinesias, but oral levodopa has not been able to meet this therapeutic goal of CDS due to pharmacological instability. Levodopa is maintained in an acidic concentration when in solution for stability purposes thus making infusion systems and transdermal delivery difficult to achieve [11]. Continuous intravenous or intraduodenal administration of levodopa is also impractical and inconvenient for patients [5]. Current clinical trials are ongoing to evaluate the use of intraduodenal infusion of methyl ester of levodopa via an infusion pump to achieve CDS. Numerous long acting formulations of dopamine agonists have been tried as a method to achieve clinical CDS without success [12]. Moreover, systemic administration of levodopa (even in the form of the methyl ester of levodopa) or the systemic administration of another dopamine agonist will still cause potential side effects because of hyperstimulation of dopamine receptors outside of the nigrostriatal pathway, which is the basis for many of the undesirable side effects (e.g., hallucinations). Unfortunately, even with the therapeutic advancements that are ongoing with the attempt to deliver the methyl ester of levodopa via a duodenal pump, the challenge to provide focal targeted CDS in the basal ganglia will not likely be accomplished. On the other hand, dopaminergic cell transplantation into the striatum and other targets innervated by the nigrostriatal pathway has the potential advantage of providing CDS locally within the 
nigrostriatal pathway, avoiding the issue of undesirable side-effects if techniques to enhance cell transplant survival and to mitigate undesirable host immune responses are optimized. Recent studies also demonstrate that dopaminergic striatal xenografts provide long-term behavioral benefits, survive in the host, form synaptic connections and "normalize" the electrophysiological changes seen in down stream basal ganglia nuclei, suggesting that such grafts could serve as a unitary solution for advanced PD that combines the effects of oral medications with that of DBS surgery [13]. Such a singular surgical approach, if optimized, would eliminate, in theory, the need for oral dopaminergic medications and the associated side effects of such therapy. This would be a major advancement to the current therapeutic approach to advanced PD that is complicated by the morbidity of patients having to take frequent doses of medication and visiting the doctor frequently for adjustment of their DBS settings. Moreover, since the clinical experience of performing surgery in mid to advanced stage PD has been optimized via our experience with DBS surgery, the technical aspects of performing cell transplantation surgery using precise techniques and selecting the right in PD patients are no longer constraints for the clinical translation of optimized cell transplantation in PD.

One major problem with cell transplantation is the issue of host immune response. The brain had been thought to be an immune privileged organ for many years and it had been thought that cell transplants into the brain could be performed without immunosuppression. Cell transplantation experiments into the brain have shown that the immune privileged status of the brain is not absolute [14]. One obvious problem with cell transplantation into the brain is that the transplantation procedure breaches, albeit briefly, the blood brain barrier when the surgeon places the needle into the brain. This transient breach permits the influx of systemic lymphocytes and key immunological molecules that have been identified in the immune response to central nervous system (CNS) grafts. Further, it is clear from recent studies that the mature brain does have a minor lymphatic drainage and $\mathrm{T}$ cell traffic to the cervical lymph nodes to permit immune vigilance [15]. The microglia in the brain perform the duties of antigen presenting cells and secrete many of the same cytokines secreted by dentritic cells outside of the CNS. Thus, it is increasingly clear that CNS immune vigilance is present and that such vigilance is specialized. There is also a known body of literature that has firmly established the notion that neurodegeneration of the nigrostriatal pathway is associated with considerable immunopathology in the substantia nigra and in the nigrostriatal pathway [16]. Although the interaction between the immune process in the host and the newly introduced dopaminergic graft has not been fully established, several lines of studies show that without the immune protection afforded by the use of cyclosporine, or other similar agents, the successful engraftment of striatal dopaminergic grafts are seriously compromised. It is also clear that continuous systemic immunosuppression using small doses of cyclosporine is capable of protecting CNS grafts for a very long time and that withdrawal of cyclosporine can provoke a deleterious immune response that compromises the survival of CNS grafts. It is also well known that continuous immunosuppression in patients has morbidity, including the direct toxicity from the immunosuppressive medications (e.g. nephrotoxicity from cyclosporine), secondary infections from chronic immunosuppression (e.g., reactivation of dormant virus leading to herpes zoster), and increasing vulnerability to nosocomial infections.

A second major issue related to the immunology of cell transplantation is the effect of the host immune system on the differentiation status of grafted cells. This is particularly important in the case where the grafted tissue is derived from pluripotent stem cells. The host immune vigilance may be critically important to eliminate grafted cells that undergo undesirable differentiation, de-differentiation or malignant change. It is well known that grafting into immunosuppressed hosts has an increased risk of graft derived tumor formation like teratomas [17]. On the other hand it is also known that certain cytokines secreted by 
immune modulators in the brain are beneficial to developing neurons and promote their viability and maturation [18]. Grafts could also serve as modulators of the host immune response to the disease process. Some graft derived cells produce growth factors and cytokines that could mitigate deleterious immunological processes that are ongoing in the host brain secondary to the pathology of PD [16, 19-21]. Altering such immunopathology could help in slowing down disease progression in the graft recipient. Obtaining the perfect equilibrium between suppression of deleterious host responses and retaining any beneficial immune responses that are required for the well being of the host is cardinal for the success of dopaminergic cell transplantation in PD.

A third issue of importance is the notion of immune modulation of synaptic connectivity between the graft and the host [22]. It is increasingly well recognized that immune mediators, via their secreted cytokines, can sculpt the synaptic connectivity between the neurons in both health and disease. Since grafted dopaminergic neurons are often of fetal, embryonic or stem cell origin, they do grow and differentiate to make synaptic connections with the host. The location of these newly formed synapses and their functional appropriateness may be remarkably altered by the host immune response mediators like glia and $\mathrm{T}$ cells. Understanding the effects of host immune responses on the newly formed grafthost connections may be critical to further optimization of cell based therapy in PD and other neurodegenerative disorders.

Therefore, if the current immunological and cell survival issues are resolved, dopaminergic cell transplantation in PD could be reexamined again as a promising modality of therapy. Conceptually, cell transplants could also be used as a way to potentially slow down the progression of PD or help reverse the pathology of relentless neurodegeneration in the host. Such host neuronal plasticity, induced as a result of cell transplantation, may be the putative mechanism for cell transplants to cause downstream "electrophysiological" normalization [13]. This would entail the notion that cell grafts into the striatum are not just simple local dopa or dopamine pumps, but active modulators of neuronal circuit function by inducing neuronal plasticity downstream in the basal ganglia and the mediators for the development of new elctrophysiological discharge patterns. In theory, replacing dopaminergic cells in the host with new dopaminergic cells and their appropriate connections would be the 'ideal' treatment for PD, if the newly transplanted cells can remain disease free and resist neurodegenerative changes [23-26]. Such treatments may have the putative benefits of mitigating deleterious host immune response to neurodegeneration and to finding therapeutic applications in PD and in other neurodegenerative diseases even outside the context of cell transplantation.

\section{Overview of Cell Transplantation Studies in PD: Focus on Immunosuppression}

A large variety of autografts, allografts and xenografts have been tested as potential therapies in PD over the past four decades. These are summarized in Table 1. These grafting experiments have been utilized as experimental therapeutic measures of continuous replenishment of dopamine derived from the graft, growth factor replacements or as methods to enhance storage of exogenous dopamine. We are unaware of specific grafting paradigms that were targeted to modulate the host immune response to the neurodegeneration in PD or grafts targeted to enhance the "normalization" of electrophysiological changes associated with PD. These may be novel areas of future research, which we will consider in this paper. 


\subsection{Autografts}

Initial studies consisted of autologous adrenal medullary dopaminergic cell transplantation into the striatum [83-86]. Cell survival of adrenal medullary grafts was problematic in clinical trials $[27,28]$. The tissue for transplantation in these studies were derived by dissecting and removing the patient's own adrenal glands in a first surgery and immediately afterwards transplanting these cells into the brain in a second surgery. The two surgeries were conducted back to back in a single session and this may have contributed to the discomfort and eventual morbidity associated with the procedure. The morbidity associated with these procedures $[27,28]$ in clinical trials and the finding that benefits from the transplants were not superior to placebo, led to the abandonment of this procedure. An attempt to improve adrenal graft survival using cografts of peripheral nerves was also abandoned due to the increased morbidity [29]. Here the idea was that schwann cells derived from the peripheral nerve could serve as a growth factor source to enhance the survival of adrenal medulla derived dopaminergic neurons [29]. This experiment did provide the basis of performing cografts of two different types of cells into the brain for PD. With modern minimally invasive surgical techniques that allow endoscopic removal of adrenal glands and stereotactic placement of striatal transplants, the morbidity could theoretically be reduced. However, with accumulating data that autologous adrenal medulla may not be very healthy in PD patients; this approach does not have much basis for a re-trial. In a similar set of studies, carotid body autografts have also been tried with limited utility and significant side effects [31-37]. These adrenal medulla and carotid body autograft studies did not use any immunosuppression and the failure of these grafts was partly blamed due to the lack of using immunosuppression, although this hypothesis remains unproven.

A very recently discovered and yet to be clinically tested source of autografts are inducible pluripotent stem cells (iPSC) [79]. These cells, derived from skin fibroblasts of the recipients, are manipulated to derive stem cells that are then differentiated into dopaminergic cells to be transplanted into the recipient striatum. In theory, since these are patient specific and derived from the patient's own skin cells they would not require immunosuppression as they are autografts. However, much to the surprise of the scientific community, recent studies in mice have shown that synergic iPSC grafts did actually induce a host immune response [17], suggesting that even in this scenario chronic daily immunosuppression is warranted for the successful functioning of the iPSC grafts. In fact, matched iPSC may be even more immunogenic that matched hES cells according to a study in mice [17]. Zhao et al. used a teratoma formation assay to examine the immunogenicity of mouse iPSC. This assay revealed genes that are over-expressed in teratomas derived from iPSC. This study found that the abnormal gene expression can induce a $\mathrm{T}$ cell dependent immune response [17]. Thus, concluding that each patient specific iPSC will need to be checked for immunogenicity prior to transplantation of the autologus cells for a customized graft.

Further testing of this hypothesis in the case of animal models of PD are anticipated, but, conceptually it is clear that iPSC grafts can provoke an immune response from the host even when the transplanted cells are derived from the host themselves. The procedures that are used to induce "stem cell" properties into mature fibroblasts have been implicated as the putative reason for the host to mount an immune response. Such autoimmune response to modified cells of host origin is well established with bone marrow transplantation paradigms and so it is quite conceivable that such a mechanism would follow suit with iPSC transplantation. Therefore from the consensus of literature it appears that even with autografts some form of immunosuppression would be necessary for the survival of dopaminergic striatal grafts.

In addition to the need of an immunosuppressed host, iPSC transplantation has many practical issues. Each iPSC is collected from the host and genetically reprogrammed to 
become pluripotent, and then it needs to be differentiated to become a dopaminergic neuron. iPSCs are pluripotent and there is a risk of iPSC transplants causing teratomas [82]. This is a major technical issue to overcome before practical translation into the clinic as a viable transplantation strategy in PD. Additionally, this method is technologically challenging and labor intensive due to quality control measures need for proper cell preparation [87]. Despite recent technological advancement with iPSC transplants [88], creating a safe individual cell graft for each PD patient will still be technically challenging due to the requirement of extensive laboratory and financial resources. Finally, the issue of whether the host donor tissue is indeed for the best tissue to derive dopaminergic cells for transplantation is not entirely clear. It is now recognized that at least some circulating blood cells and protein products in PD patients are biomarkers for neurodegneration in the brain [89]. Although the source of these biomarkers in blood are unknown, it is quite conceivable that changes in the cellular make up is present throughout the body in various cells in patients with PD even though the manifestations are predominantly due the more severe pathology in the substantia nigra and its connections. This theory is fortified by the findings of Braak et. al., demonstrating that pathology is more widespread in the brain than in the substantia nigra in early PD [90]. So, much like what was discovered with adrenal medulla autografts, it is unclear whether donor fibroblast cells derived from a PD patient can be optimal for use in the preparation of iPSCs or whether such cells are ideal for genetic manipulations that are required to generate iPSC.

\subsection{Allogenic FVM transplants}

The vast majority of studies in PD cell transplantation to date have utilized fetal ventral mesencephalic (FVM) cells. The FVM tissue represents the fetal progenitor for the nigrostriatal pathway and when harvested at the correct time point can be successfully transplanted into a host and allowed to reform the nigrostriatal pathway. Over the years it held the most promise as a tissue source for transplantation in PD. In fact, human FVM tissue became the gold standard for cell based behavioral therapies in PD and has shown the greatest clinical benefits to date. These cells make synaptic connections with the host, thus; the graft has the ability, in theory, to provide regulated release of dopamine [91-93]. As noted in the beginning of this paper, the substantia nigra is located in the mid-brain and the axons traverse some distance to reach the striatum in the adult. Due to the distances involved, all transplantation trials of allogenic FVM have been attempted hetreotopically by placing the grafts directly into the striatum. A few investigators have placed simultaneous dual grafts into the striatum and into the substantia nigra, but the nigral grafts have never successfully grown to recreate the nigrostriatal pathway in the human. Attempts have also been made to place small multiple grafts in the extrastriatal sites and in the striatum with some success in animal models. However, more recent studies suggest that such multiple FVM grafts may not impart any advantage. The immunological consequence of multiple grafts is also unknown. There have been spectacular success stories of FVM allografts in animals that have restored animals to complete health from severe parkinsonism and the majority of these animal studies have required continuous immunosuppression for successful engraftment and function. Several open-label studies in PD patients have also been successful and all of them have either required short term or long-term immunosuppression. However, placebo controlled double blind studies of FVM in advanced PD failed to meet the desired goals of exceeding the effects of sham surgery [38-48] and caused severe side effects called graft-induced dyskinesias (GID) [25]. Although the exact causes of these failed trials have never been completely resolved, many technical issues and the premature discontinuation of immunosuppression have been implicated as putative causes for the failure. 
There are other significant limitations for clinical translation of FVM even if the methodological and technical issues are ironed out. There is a restricted window of time available between the time a fetus can be dissected to obtain the necessary tissue and its viability as a transplant. Thus delay of transplantation requires prolonged storage. Such storage and delays put the graft tissue at risk for contamination with different organisms and compromise the viability of the graft. Storage may also make the grafts more prone to immune response from the host. Moreover, ethical issues arise with the use of FVM tissue due to the fact six to eight fetuses are need for clinically beneficial effects [91]. It is also evident that even well matched allogenic FVM grafts become vulnerable to deleterious host immune response with upregulation of the host CNS immune response mediators following the surgical procedure, therefore, host immunosuppression is necessary. In fact, most patients transplanted with allogenic FVM and who developed disabling GID did so after systemic immunosuppression was discontinued [94, 95]. In contrast, FVM allograft recipients who continued to receive chronic immunosuppression remained resistant to GID [96].

A limited number of autopsy studies on patients who received FVM grafts and had died from unrelated causes show that grafted allogenic FVM neurons may develop degenerative changes that emulate PD pathology [23, 24, 26]. Many patients who came up for autopsy had been off immunosuppression for many months. One putative explanation for the presence of Lewy bodies and PD pathology in grafted neurons is the notion that a deleterious host immune response could have led to this pathology [97, 98].

Recent animal studies using FVM have also shown very interesting findings. Soderstrom et al. have shown in animal models using electron microscopy that cell transplantation with allogenic FVM cells tend to form aberrant synapses, making asymmetric connections that lead to abnormal focal excitatory action on striatal medium spiny neurons [22]. These atypical synaptic features strongly correlate with the immune response and the appearance of GID [22]. An additional challenge related to the immune function of the CNS is the risk of inappropriate hyperinnervation of the host derived from the graft and/or aberrant synapse formation with the host. There are indications that host immune response may play significant deleterious role in the genesis of such aberrant connectivity. Studies with allogenic FVM transplants have suggest that GID may be related to aberrant synaptic connectivity, hyperinnervation of host, and possible inclusion of non-dopaminergic cells in grafted tissue [99]. In animal models, FVM cells tend to from aberrant synapses, thus making asymmetric connections that allow an abnormal focal excitatory driving action on the striatal medium spiny neurons [22]. These synaptic irregularities correlated with behavioral measures of GID [22] and it is thought that a large contributing factor to the formation of these abnormal synapses is the host immune response [22, 99].

Additionally, research suggests that serotonin neurons inadvertently included within dopamineric grafts are another player in the development of GID. Serotonin neurons contain L-dopa converting aminoacid aromatic decarboxylase enzyme and have the vesicular monoamine transporter 2 , therefore these neurons are capable of storing and releasing dopamine [100-102]. It is possible that the inclusion of serotonin neurons in the graft could cause GID. This notion has been supported in animal studies [102-107]. Furthermore clinical studies using 5- $\mathrm{HT}_{1 \mathrm{~A}}$ partial agonists (studies with both Buspirone and Sarizotan) to test the anti-GID effects support this hypothesis. It likely that serotonergic neurons are inappropriately transplanted along with the dopaminergic cells and such cells play a role in the genesis of GID; however, it is unclear whether host immune factors play a role in the survival of these serotonin secreting neurons within dopaminergic grafts and whether immune mediators play a role in allowing such serotonin secreting cells to serve as 
modulators of dopamine. Additional investigations are warranted to evaluate such interactions between host immune mediators and specific types of transplanted cells.

Despite these drawbacks, numerous individual patients have had spectacular long-term benefits following FVM allografts for PD related motor disability. This is in sharp contrast to some individuals who developed GID. The patients that had the best benefits with FVM allografts were younger in age, had received single cell suspension of FVM and had received long-term immunosuppression with cyclosporine for several years in a continuous fashion. Many patients who received single suspension of FVM as striatal grafts and were continuously treated with immunosuppressive medications lead exceptional lives lacking any major disability. This finding suggests that finding the right patient and using the correct techniques can potentially provide such patients with exceptional therapy to ameliorate parkinsonian disability.

In summary, allogenic FVM grafting experiments have shown that such grafts require precise tissue dissection to avoid contamination with other tissue or cells, precise and quick placement into the striatum with minimally invasive techniques, transplant recipients must have a more intact nigrostriatal dopaminergic system than what is seen in most advanced PD patients and, most importantly, long-term immunosuppression is necessary. Despite extensive testing, many issues remain including the issue of aberrant connectivity, GID, grafts acquiring PD pathology and ethical issues.

\subsection{FVM Xenografts}

To avoid the ethical issues of using human FVM tissue, studies have examined the use of porcine FVM tissue as an alternative transplant [50-59]. In contrast to the human FVM tissue, porcine tissue is relatively easy to obtain and harvest can be timed accordingly to transplant days. However, xenografts require a form immunosuppression to prevent host immune rejection; in fact, a hyperacute rejection can occur in xeonografts due to the presence of preformed antibodies. Another concern about using porcine FVM tissue is the risk of contracting zoonotic infections. Porcine FVM xenotransplantation appeared to be a safe alternative to allogenic FVM transplantation in many animal studies. However, FVM xenotransplantation failed clinical trials and required lifelong system immunosuppression or antigen masking of donor tissue.

FVM xenografts have also been used to evaluate electrophysiology and immunology in animal models of PD [13]. Mouse FVM is well tolerated in parkinsonian rat host if the animal is continuously immunosuppressed. Such grafts show excellent cell survival, graft host connectivity and cause behavioral recovery in these parkinsonian animals. Electrophysiological studies in these animals show remarkable changes in neuronal discharge patterns in basal ganglia structures that are downstream to the site of graft placement in the striatum. Surprisingly, these electrophysiological recordings from the subthalamic nucleus and the substantia nigra pars reticulata in these FVM xenografted animals are closer to what is seen in the normal animal. Hemiparkinsonian animals treated with strict regimen of levodopa treatments failed to replicate the effects of FVM xenotransplants into the striatum [13]. These results suggest that beyond the notion of CDS provided via a dopaminergic striatal graft, these FVM xenotransplants are able to provide long-term plastic changes in the circuits that modulate the neuronal discharge patterns in the basal ganglia pathways. Moreover, FVM xenografts into the striatum in these parkinsonian rats appear to mimic the behavioral consequence of the combined used of dopaminergic medications and DBS in advanced PD patients. Advanced PD patients in contemporary medicine who develop either medication refractory motor complications or medication induced side-effects are operated upon for the implantation of DBS electrodes and electrically stimulated to abolish the deleterious electrophysiological discharge patterns in 
the subthalamic nucleus, its connections or adjacent areas. Striatal FVM xenografts appear to achieve the combined effects of dopaminergic therapy and DBS of the basal ganglia. How this is achieved and whether the host immune response has anything to do with this apparent neuronal plasticity is entirely unclear and is a subject for future investigation.

In summary, immunological lessons from xenografted FVM are similar to that of allogenic FVM. As expected xenografts require immunosuppression, but unexpectedly, graft survival, connectivity and behavioral benefits were no different between allogenic and xenogenic FVM, suggesting that the species of origin of the tissue is not cardinal for the success of grafting or for its functional integration with the host, at least in animal models of PD. In human clinical trials xenografts of FVM were not successful and had to be abandoned. However in recent studies, xenografted FVM in PD animal models demonstrate that such grafts provide long-term plastic changes down steam in the basal ganglia that were not reproduced by intermittent systemic dosing of levodopa, further strengthening the case for the use of local focused CDS into the striatum for clinical therapy in PD via the use of a dopaminergic graft or another alternative method.

\subsection{Human Retinal Pigment Epithelial Cell Transplants}

hRPECs have been studied as an alternative to human and porcine FVM tissue transplants. These cells can be grown and expanded in tissue culture while being stored for prolonged periods of time, providing an advantage over the use of human FVM allografts, porcine xenografts, adrenal and carotid body autografts. In addition, hRPEC from a single donor eye could potentially treat several hundred patients, minimizing ethical concerns. hRPECs secrete L-dopa, a unique growth factor called pigment epithelium derived growth factor (PEDF), small amounts of glial derived neurotrophic factor (GDNF), platelet-derived growth factor (PDGF), epidermal growth factor (EGF), vascular endothelial growth factor (VEGF), and nitric oxide [108]. hRPECs attached to microcarriers can be stereotactically transplanted into the striatum without the use of immunosuppression [62]. Furthermore, hRPECs have been known to have immunosuppressive properties in the eye and are the critical component of the blood-eye barrier [109-112]. It is thought that the survival of hRPEC grafts in the brain can be attributed to these immunosuppressive properties [108].

Striatal xenotransplants of hRPEC of embryonic origin in non-immunosuppressed parkinsonian animals and allografts in advanced PD patients have shown significant amelioration of parkinsonism with no evidence of host immune response or graft rejection five years after transplantation. Specifically, hRPEC xenografts into parkinsonian rats and monkeys caused statistically significant and sustained improvement of parkinsonism when compared to controls [108]. Hemi-parkinsonian monkeys were behaviorally assessed 18 months post-transplant and statically significant improvement in parkinsonism was seen along with histological examination showing $75 \%$ cell survival of the graft [108]. In addition, minimal inflammatory response was seen in and around the injection tracts within the striatum. Similar recent studies from several additional laboratories show that hRPEC grafts improved behavioral outcomes in hemiparkinsonian rat models and hRPEC grafts provide a source of neurotropic factors $[65,67,70,71]$. Other studies suggest that PEDF secreted by the hRPEC transplants may have had a role in improving symptoms of PD [66, 69].

Initial human pilot studies in six young, advanced idiopathic PD patients demonstrated that embryonic origin hRPEC transplants were well tolerated without serious adverse effects within an observation period of 60 months $[63,64]$. This Phase I open label trial showed clinically and statistically significant improvements from baseline to post-transplantation in the Unified Parkinson Disease Rating Scale that was sustained over 60 months without adverse effects. However, the Spheramine Safety and Efficacy Study (STEPS trial, a double 
blind prospective trial of hRPEC attached to microcarriers in advanced PD patients) showed a lack of statistically significant improvement between hRPEC transplanted patients versus control patients, although both groups of patients had sustained improvement in parkinsonism compared to pre-transplantation baseline assessments [113]. Unlike previous studies with embryonic origin hRPEC, the STEPS trial used post-natal hRPEC derived from a "live birth donor" with a birth certificate as required by German law (study sponsor was Schering AG, a company based in Germany). A single partial autopsy (one-half brain) autopsy report that describes pathological findings of a subject enrolled in the STEPS trial has been published [68]. This report came from a 68-year old patient with 18 year history of parkinsonism who sustained a fall 5 months after the transplant surgery and a purulent lung infection that did not respond to therapy. This patient reported no motor benefits posttransplant [68]. Relatively few hRPECs were observed in the graft sites with some macrophage infiltration within needle tracts with site to site variability; however, there was no extensive macrophage infiltration [68].

Farag et. al, acknowledge that previous autopsy studies from CNS transplantation have shown within the same subject, and the same hemisphere, near 100-fold differences in cell survival between tracts, while interhemispheric differences ranging from absence of survival to survival of 100,000 cells $[41,114]$. Therefore, Farag et. al., concede that the low hRPEC count that they obtained could be due to the limited examination of one hemisphere [68]. Addition limitations included the use of manual counts as opposed to unbiased stereological counts or neurodegeneration of transplanted cells [68]. However, no Lewy Bodies were found within transplanted hRPEC [68]. Farag et. al., report the presence of macrophages in the transplant sites along with CD8 positive T-cells and absence of CD19 and CD4 immunoreactivity [68]. Peripheral blood derived macrophages are rare in the healthy brain [115], but are known to occur in patients with PD that have a permissive blood brain barrier and has been proposed as a method to deliver therapeutic molecules [116]. One theory proposed is that there was host immune response in the brain directed against the post natal hRPEC grafts sometime close to death. The pathology of such a delayed induction of host immune response has been studied in great detail (e.g., [117];see Table 2 for additional studies). This immune reaction is characterized by MHC class I and class II positive microglial reaction that surrounds the graft site, intense perivascular cuffing and $\mathrm{T}$ cell infiltration [117]. Such pathology was noted in the autopsy. A second hypothesis is that host immune attack of the graft had been going on for 6 months since transplantation. The host immune response in the absence of immunsuppression to CNS allograft is complete by the end of the fourth week leaving little or no residual graft in the brain (e.g., [118-120]; see Table 2 for listing of studies). Thus this hypothesis is inconsistent with published literature on CNS allografts. An alternate hypothesis not considered by Farag et.al., is the possibility of a chronic systemic inflammation provoked in response the lung infection that caused the patient's death. Such a systemic inflammatory response to infection cause macrophage accumulation around any foreign body including CNS grafts attached to microcarriers [121]. In summary, the interpretation of the data from this single limited autopsy report is problematic and additional studies from post-natal hRPEC are warranted.

Gross et. al., equate post-natal hRPEC that was used in the STEPS trial to the embryonic hRPEC that were used in all preclinical and clinical studies $[62-64,67,70,71,91,108]$ that preceded the STEPS trial. There are no studies that provide such preclinical or clinical equivalence published to date and there are numerous studies suggesting that embryonic hRPEC are unique and show functional differences compared to more mature sources of hRPEC [122, 123]. One putative reason for the failure of the STEPS trial could be the switch to post natal hRPEC in lieu of the embryonic hRPEC. Some credibility to this hypothesis is borne by the dramatic difference in outcomes in the open-label trial of six advanced PD patients who continue to benefit from unilateral hRPEC grafts of embryonic 
origin for over 10 years without any GID or other adverse events and without any loss of efficacy of the anti-parkinsonian benefits[63, 64].

\subsection{Human Embryonic Stem Cell Transplantation}

Unlike the hRPEC that maintain their epithelial phenotype following successful engraftment, hES cells differentiate to extend neurites that form functional synaptic connections with the host [74]. However, to date hES derived dopaminergic cells have not reached clinical trials. There are a number of key factors that preclude such translation at the present time although promising advancements are being made. Similar to FVM allografts and xenografts, in theory, synaptic connections between the host and the graft could be made by hES dopaminergic graft that may provide better modulation of graft derived neurotransmitter release. This finding of graft host connectivity derived from $\mathrm{hES}$ has only been achieved in very recent studies [77, 124]. This may be an advantage for hES grafts over hRPEC grafts as the later do not form synapses. However, the notion of whether synaptic connectivity between the host and the graft is cardinal for functional recovery in PD remains a subject of intense debate.

All hES derived dopaminergic cell transplantation studies in animal models published to date have chosen to use systemic immunosuppression throughout the study duration [72-74, $77,124]$. In one study, 500,000 hES cells were transplanted [72]; after 10 weeks less than 200,000 cells survived and these investigators were able to estimate fewer than 20,000 tyrosine hydroxylase $(\mathrm{TH})$ positive cells in the striatum even in the presence of systemic immunosuppression. In a second study $480,000 \mathrm{hES}$ dopaminergic cells were transplanted with immunosuppression. At the end of 32 weeks these investigators estimated a mean survival of 5,385 TH positive grafted neurons [73, 74]. Interestingly, even in the presence of systemic immunosuppression, nearly $85 \%$ of the transplanted hES cells did not survive transplantation into the CNS. It is apparent that such a massive amount of cell death in hES striatal transplants will be accompanied by a host immune response. Therefore, methods to avoid such massive cell death will be necessary to achieve the goal of successful hES derived dopaminergic transplantation in PD.

Many other studies have supported this need for immunosuppression with hES grafting [73-76, 125]. The most recent study by Kriks et al. using new methods of hES differentiation, cyclosporine A (started 24 hours prior to surgery until death) was required to achieve sufficient TH positive cells to see behavioral benefits in 6-hydroxydopamine lesioned rats [77]. Similarly, the animals in the primate studies received cyclosporine A orally throughout the study duration [77]. In summary, hES derived dopaminergic neurons hold promise as putative next generation grafts to provide CDS in PD. However, immunosuppression of the host is required for these grafts to succeed and the ethical objections to the use of embryonic stem cells remain.

\section{Possible Future Directions to Avoid Systemic Immunosuppression}

It is now clear that immunomodulation of the host microenvironment, the recipient site of cell grafts, has to be achieved in order to successfully accomplish cell transplantation in PD. This is illustrated via numerous preclinical and clinical studies that were discussed above. Table 1 summarizes several of these key transplantation approaches and their outcomes though preclinical research studies and clinical trials in PD. Table 2 summarizes key immunological experiments that show the need for immunosuppression in hosts of different ages for cell transplantation into the brain and the consequences of withdrawal of immunosuppression or provocative maneuvers that can upregulate the host immune response to grafts. The provocative experiments described in Table 2 are experimental scenarios that are often mimicked by common illness in elderly PD patients. For example, 
upregulation of interferon levels is common in PD and in animal models of PD [126-128] and such upregulation of serum cytokines occur with common viral illnesses that effect the elderly. Increase in interferon levels can cause even well-integrated CNS grafts to become vulnerable to immune attack from a rejuvenated immune system in response to such infections or persistent degenerative process in the brain as demonstrated in these experiments [117]. Transient disruption of the blood brain barrier is also common in PD patients $[129,130]$. Moreover, elderly patients with PD are also under age associated risk for transient ischemic attacks and microvascular changes that contribute to disruptions in the blood brain barrier. Such transient or persistent breakdown in the blood brain barrier also contributes to the long term vulnerability of CNS grafts to delayed immune attack from the host immune system that has access to the brain via a leaky blood brain barrier.

Degenerative changes in the peripheral nervous system is also quite common in PD patients [131]. Such degeneration cause breakdown of the blood CSF barrier at the nerve root level and contribute to upregulation of immunological changes at the junction of the CNS and peripheral nervous system permitting additional systemic immune mediators access to the brain that was previously not present. This mechanism is also a viable trigger of a host immune attack on well integrated dopaminergic grafts in PD patients. These experimental results from a diverse group of CNS grafts shown in Table 2 illustrate the need for CNS grafts to require continued long term (perhaps life long in the case of PD patients) immunosuppression to protect grafts from a host immune attack and subsequent loss of function. Table 2 shows that neonatal hosts are much more tolerant to CNS grafts, but, this really does not apply to PD, as it is an adult onset disease. However, a comparison of various key studies in the immunology of cell transplantation is afforded via this table illustrating the compelling need for immunomodulation for all CNS cell transplants in adult hosts. This table also summarizes some of the successful methods used to overcome the issue of host immune response to cell transplantation in the brain. Perhaps, if the conditions that promote graft survival in these successful situations can be mimicked, PD cell transplantation can be more successful.

Despite discouraging outcomes in some of the clinical trials, there is much promise to come in cell transplantation for PD. The importance of immunology in CNS transplantation is becoming increasing apparent [14]. Antigen presenting cells (APCs), major histocompatibility antigens (MHC) class I and II molecules, co-stimulatory ligands, and activated T cells are key mediators in the cell-mediated immune response to CNS grafts. Immunosuppression is important for functional survival of grafts into the striatum in PD. However as discussed earlier, long-term systemic immunosuppression in transplanted patients has many unwanted side effects. As noted in Table 1 and 2, embryonic hRPEC transplants appear to be an exception to the rule of needing of chronic immunosuppression. Furthermore, hRPECs are known to secrete immunosuppressive substances that could potentially provide an environment that is conducive for the survival of a healthy cell graft [62, 109-112].

hES cells, iPSC, and hRPECs are the latest generation of dopaminergic cell transplants that potentially have shown promise as dopamine replacement therapies for the long-term successful treatment of PD. We discussed the promise and pitfalls of iPSC derived dopaminergic cells and as a practical matter verifying the toxicity and safety of iPSC for each individual patient would require extensive and expensive analysis. Thus until this issue is resolved iPSC do not appear to be viable candidates for clinical translation as autografts. However, iPSC obtained from healthy humans and used as allografs; and hES derived dopaminergic cells offer a more immediate translational potential. Combining hES derived dopaminergic cells or iPSC derived dopaminergic cells with hRPECs could provide a novel cograft that could prevent the rejection of the engrafted tissue in a non-immunosuppressed host (see Figure 1 for proposed mechanism). 
Using hRPEC cografts to provide ongoing local immunosuppression and trophic support could be a major advantage by avoiding the morbidity associated with systemic immunosuppression. In theory, embryonic hRPEC or other immunomodulatory cells, like sertoli cells, and perhaps umbilical cord stem cells, may have the ability to provide local immunosuppression when cografted with hES cells [159-161]. Since hRPEC grafts in PD have been extensively tested and embryonic origin hRPEC has had the best clinical and preclinical success to date with very little or no adverse effects, it would be potentially advantageous to initially test the cografting of embryonic origin hRPEC with hES derived dopaminergic grafts in animal models of PD.

Another alternative would be to place a local infusion catheter at the site of hES derived dopaminergic grafts that is connected to an implanted extracranial infusion pump to deliver immunomodulators locally into the brain. In theory, this would have the advantage of a specific therapy as the infusion will be an identified agent like a known immune mediator or an immunosuppressive agent. However, this would be a mechanical device and catheter system that would come with its own set of inherent risks. In addition, such an infusion system is unlikely to provide the combination of local immunosuppression, trophic and antiteratoma effects that a cellular cograft like hRPEC may be able to provide.

Yet another method to deliver local immunosuppression would be to use microcarriers impregnated with immune mediators that are slow released (e.g., [156]) that could be implanted alongside the hES derived or iPSC derived allogenic dopaminergic Piquet and Subramanian - 31 grafts. The disadvantage again would be that such co-implanted microcarriers would have a finite life span and would have to be replaced with repeat surgery. Also, such implants may carry additional surgical risks and they would suffer from the same disadvantage as implanted pumps as they would not have the cellular multitasking abilities of cografts like hRPEC or other similar immune modulating cell co-grafts.

Various immunosuppressive alternatives to cyclosporine such as other calcineurin inhibitors, glucocorticoids, polyclonal and monoclonal antibodies, and cytostatic drugs are also being explored (e.g., [162]). However, these agents are associated with iatrogenic clinically significant systemic immunodeficiency, increased susceptibility to infections and decreased cancer immunosurveillance. Newer systemic agents that are not associated with such risks and provide targeted immunomodulation in the CNS would be highly desirable to advance cell transplantation in PD as a therapy.

In summary, cell transplantation continues to be a promising therapeutic method for PD. Advances in the scientific and technical aspects of cell transplantation continue to improve the efficacy of this therapy. However, it is clear that transplantation methods have not been successful in meeting all the therapeutic goals in PD treatment. Previously reviewed studies have demonstrated that limiting the cell-mediated chronic immune response can increase graft survival and functionality. Other modalities to avoid this host immune response, possibly in the form of cografts, need to be explored further.

\section{Acknowledgments}

This work is funded in part by NINDS study NS42402 and Pennsylvania Tobacco Settlement Fund awarded to Subramanian, T., American Parkinson's disease Association (APDA) and Barsumian Trust funding to Venkiteswaran, K, APDA and Parkinson's Disease foundation summer research fellowships awarded to Piquet, A. and Marupudi, N. respectively. This work was also supported by the American Academy of Neurology Extended Neuroscience Essay Awarded to Piquet, A. 


\section{References}

1. Olanow CW, Stern MB, Sethi K. The scientific and clinical basis for the treatment of Parkinson disease (2009). Neurology. 2009; 72(21 Suppl 4):S1-136. [PubMed: 19470958]

2. Marsden CD. Problems with long-term levodopa therapy for Parkinson's disease. Clin Neuropharmacol. 1994; 17(Suppl 2):S32-44. [PubMed: 9358193]

3. Fabbrini G, Juncos J, Mouradian MM, Serrati C, Chase TN. Levodopa pharmacokinetic mechanisms and motor fluctuations in Parkinson's disease. Ann Neurol. 1987; 21(4):370-6. [PubMed: 3579222]

4. Chase TN, Juncos J, Serrati C, Fabbrini G, Bruno G. Fluctuation in response to chronic levodopa therapy: pathogenetic and therapeutic considerations. Adv Neurol. 1987; 45:477-80. [PubMed: 3103391]

5. Chase TN. Levodopa therapy: consequences of the nonphysiologic replacement of dopamine. Neurology. 1998; 50(5 Suppl 5):S17-25. [PubMed: 9591518]

6. Benabid AL. What the future holds for deep brain stimulation. Expert Review of Medical Devices. 2007; 4(6):895-903. [PubMed: 18035954]

7. Lyons KE, Wilkinson SB, Overman J, Pahwa R. Surgical and hardware complications of subthalamic stimulation: a series of 160 procedures. Neurology. 2004; 63(4):612-6. [PubMed: 15326230]

8. Bibbiani F, Costantini LC, Patel R, Chase TN. Continuous dopaminergic stimulation reduces risk of motor complications in parkinsonian primates. Exp Neurol. 2005; 192(1):73-8. [PubMed: 15698620]

9. Juncos JL, Engber TM, Raisman R, Susel Z, Thibaut F, Ploska A, Agid Y, Chase TN. Continuous and intermittent levodopa differentially affect basal ganglia function. Annals of Neurology. 1989; 25(5):473-8. [PubMed: 2774488]

10. Mouradian MM, Heuser IJ, Baronti F, Fabbrini G, Juncos JL, Chase TN. Pathogenesis of dyskinesias in Parkinson's disease. Annals of Neurology. 1989; 25(5):523-6. [PubMed: 2774496]

11. Olanow CW. Levodopa/dopamine replacement strategies in Parkinson's disease--future directions. Mov Disord. 2008; 23(Suppl 3):S613-22. [PubMed: 18781663]

12. Fernandez HH, Odin P. Levodopa-carbidopa intestinal gel for treatment of advanced Parkinson's disease. Curr Med Res Opin. 2011; 27(5):907-19. [PubMed: 21351823]

13. Gilmour TP, Piallat B, Lieu CA, Venkiteswaran K, Ramachandra R, Rao AN, Petticoffer AC, Berk MA, Subramanian T. The effect of striatal dopaminergic grafts on the neuronal activity in the substantia nigra pars reticulata and subthalamic nucleus in hemiparkinsonian rats. Brain. 2011

14. Barker R, Widner H. Immune problems in central nervous system cell therapy. NeuroRx. 2004; 1:472-481. [PubMed: 15717048]

15. Weller RO, Djuanda E, Yow HY, Carare RO. Lymphatic drainage of the brain and the pathophysiology of neurological disease. Acta Neuropathol. 2009; 117(1):1-14. [PubMed: 19002474]

16. Appel SH, Beers DR, Henkel JS. T cell-microglial dialogue in Parkinson's disease and amyotrophic lateral sclerosis: are we listening? Trends Immunol. 2009; 31(1):7-17. [PubMed: 19879804]

17. Zhao T, Zhang ZN, Rong Z, Xu Y. Immunogenicity of induced pluripotent stem cells. Nature. 474(7350):212-5. [PubMed: 21572395]

18. Michel-Monigadon D, Bonnamain V, Nerriere-Daguin V, Dugast AS, Leveque X, Plat M, Venturi E, Brachet P, Anegon I, Vanhove B, Neveu I, Naveilhan P. Trophic and immunoregulatory properties of neural precursor cells: benefit for intracerebral transplantation. Exp Neurol. 2010; 230(1):35-47. [PubMed: 20470774]

19. McGeer PL, McGeer EG. Glial reactions in Parkinson's disease. Mov Disord. 2008; 23(4):474-83. [PubMed: 18044695]

20. Tansey MG, Frank-Cannon TC, McCoy MK, Lee JK, Martinez TN, McAlpine FE, Ruhn KA, Tran TA. Neuroinflammation in Parkinson's disease: is there sufficient evidence for mechanism-based interventional therapy? Front Biosci. 2008; 13:709-17. [PubMed: 17981581] 
21. Tansey MG, Goldberg MS. Neuroinflammation in Parkinson's disease: its role in neuronal death and implications for therapeutic intervention. Neurobiol Dis. 2009; 37(3):510-8. [PubMed: 19913097]

22. Soderstrom KE, Meredith G, Freeman TB, McGuire SO, Collier TJ, Sortwell CE, Wu Q, SteeceCollier K. The synaptic impact of the host immune response in a parkinsonian allograft rat model: Influence on graft-derived aberrant behaviors. Neurobiol Dis. 2008; 32(2):229-42. [PubMed: 18672063]

23. Kordower JH, Chu Y, Hauser RA, Freeman TB, Olanow CW. Lewy body-like pathology in longterm embryonic nigral transplants in Parkinson's disease. Nature Medicine. 2008; 14(5):504-6.

24. Kordower JH, Chu Y, Hauser RA, Olanow CW, Freeman TB. Transplanted dopaminergic neurons develop PD pathologic changes: a second case report. Mov Disord. 2008; 23(16):2303-6. [PubMed: 19006193]

25. Olanow CW, Gracies JM, Goetz CG, Stoessl AJ, Freeman T, Kordower JH, Godbold J, Obeso JA. Clinical pattern and risk factors for dyskinesias following fetal nigral transplantation in Parkinson's disease: a double blind video-based analysis. Mov Disord. 2009; 24(3):336-43. [PubMed: 19006186]

26. Li JY, Englund E, Holton JL, Soulet D, Hagell P, Lees AJ, Lashley T, Quinn NP, Rehncrona S, Bjorklund A, Widner H, Revesz T, Lindvall O, Brundin P. Lewy bodies in grafted neurons in subjects with Parkinson's disease suggest host-to-graft disease propagation. Nat Med. 2008; 14(5): 501-3. [PubMed: 18391963]

27. Goetz CG, Stebbins GT 3rd, Klawans HL, Koller WC, Grossman RG, Bakay RA, Penn RD. United Parkinson Foundation Neurotransplantation Registry: multicenter US and Canadian data base, presurgical and 12 month follow-up. Prog Brain Res. 1990; 82:611-7. [PubMed: 2290962]

28. Goetz CG, Stebbins GT 3rd, Klawans HL, Koller WC, Grossman RG, Bakay RA, Penn RD. United Parkinson Foundation Neurotransplantation Registry on adrenal medullary transplants: presurgical, and 1- and 2-year follow-up. Neurology. 1991; 41(11):1719-22. [PubMed: 1944898]

29. Watts RL, Subramanian T, Freeman A, Goetz CG, Penn RD, Stebbins GT, Kordower JH, Bakay RA. Effect of stereotaxic intrastriatal cografts of autologous adrenal medulla and peripheral nerve in Parkinson's disease: two-year follow-up study. Exp Neurol. 1997; 147(2):510-7. [PubMed: 9344575]

30. Kompoliti K, Chu Y, Shannon KM, Kordower JH. Neuropathological study 16 years after autologous adrenal medullary transplantation in a Parkinson's disease patient. Movement Disorders. 2007; 22(11):1630-3. [PubMed: 17534949]

31. Porzionato A, Macchi V, Parenti A, De Caro R. Trophic factors in the carotid body. Int Rev Cell Mol Biol. 2008; 269:1-58. [PubMed: 18779056]

32. Minguez-Castellanos A, Escamilla-Sevilla F, Hotton GR, Toledo-Aral JJ, Ortega-Moreno A, Mendez-Ferrer S, Martin-Linares JM, Katati MJ, Mir P, Villadiego J, Meersmans M, Perez-Garcia M, Brooks DJ, Arjona V, Lopez-Barneo J. Carotid body autotransplantation in Parkinson disease: a clinical and positron emission tomography study. J Neurol Neurosurg Psychiatry. 2007; 78(8): 825-31. [PubMed: 17220289]

33. Rafael H. Autotransplantation of human carotid body cell aggregates for treatment of Parkinson's disease. Neurosurgery. 2004; 54(4):1035-6. [PubMed: 15088623]

34. Arjona V, Minguez-Castellanos A, Montoro RJ, Ortega A, Escamilla F, Toledo-Aral JJ, Pardal R, Mendez-Ferrer S, Martin JM, Perez M, Katati MJ, Valencia E, Garcia T, Lopez-Barneo J. Autotransplantation of human carotid body cell aggregates for treatment of Parkinson's disease. Neurosurgery. 2003; 53(2):321-8. discussion 328-30. [PubMed: 12925247]

35. Cao X, Sun S, Tong E. Experimental study on heterograft of glomus cells of carotid body for hemiparkinsonian rats. J Huazhong Univ Sci Technolog Med Sci. 2002; 22(2):129-31. [PubMed: 12658754]

36. Toledo-Aral JJ, Mendez-Ferrer S, Pardal R, Echevarria M, Lopez-Barneo J. Trophic restoration of the nigrostriatal dopaminergic pathway in long-term carotid body-grafted parkinsonian rats. Journal of Neuroscience. 2003; 23(1):141-8. [PubMed: 12514210] 
37. Espejo EF, Montoro RJ, Armengol JA, Lopez-Barneo J. Cellular and functional recovery of Parkinsonian rats after intrastriatal transplantation of carotid body cell aggregates. Neuron. 1998; 20(2):197-206. [PubMed: 9491982]

38. Freed CR, Greene PE, Breeze RE, Tsai WY, DuMouchel W, Kao R, Dillon S, Winfield H, Culver S, Trojanowski JQ, Eidelberg D, Fahn S. Transplantation of embryonic dopamine neurons for severe Parkinson's disease.[see comment]. New England Journal of Medicine. 2001; 344(10):7109. [PubMed: 11236774]

39. Goetz CG, Penn RD, Klawans HL. Fetal-tissue transplantation for Parkinson's disease.[comment]. New England Journal of Medicine. 1993; 329(20):1498. author reply 1499-500. [PubMed: 8413464]

40. Goetz CG, Poewe W, Rascol O, Sampaio C. Evidence-based medical review update: pharmacological and surgical treatments of Parkinson's disease: 2001 to 2004. Movement Disorders. 2005; 20(5):523-39. [PubMed: 15818599]

41. Kordower JH, Rosenstein JM, Collier TJ, Burke MA, Chen EY, Li JM, Martel L, Levey AE, Mufson EJ, Freeman TB, Olanow CW. Functional fetal nigral grafts in a patient with Parkinson's disease: chemoanatomic, ultrastructural, and metabolic studies. Journal of Comparative Neurology. 1996; 370(2):203-30. [PubMed: 8808731]

42. Kordower JH, Sortwell CE. Neuropathology of fetal nigra transplants for Parkinson's disease. Progress in Brain Research. 2000; 127:333-44. [PubMed: 11142034]

43. Lindvall O, Rehncrona S, Brundin P, Gustavii B, Astedt B, Widner H, Lindholm T, Bjorklund A, Leenders KL, Rothwell JC, et al. Human fetal dopamine neurons grafted into the striatum in two patients with severe Parkinson's disease. A detailed account of methodology and a 6-month follow-up. Arch Neurol. 1989; 46(6):615-31. [PubMed: 2786405]

44. Olanow CW, Goetz CG, Kordower JH, Stoessl AJ, Sossi V, Brin MF, Shannon KM, Nauert GM, Perl DP, Godbold J, Freeman TB. A double-blind controlled trial of bilateral fetal nigral transplantation in Parkinson's disease. Ann Neurol. 2003; 54(3):403-14. [PubMed: 12953276]

45. Sladek JR Jr. Redmond DE Jr. Collier TJ, Blount JP, Elsworth JD, Taylor JR, Roth RH. Fetal dopamine neural grafts: extended reversal of methylphenyltetrahydropyridine-induced parkinsonism in monkeys. Progress in Brain Research. 1988; 78:497-506. [PubMed: 3266802]

46. Sladek JR Jr. Redmond DE Jr. Collier TJ, Haber SN, Elsworth JD, Deutch AY, Roth RH. Transplantation of fetal dopamine neurons in primate brain reverses MPTP induced parkinsonism. Progress in Brain Research. 1987; 71:309-23. [PubMed: 3495818]

47. Taylor JR, Elsworth JD, Roth RH, Sladek JR Jr. Collier TJ, Redmond DE Jr. Grafting of fetal substantia nigra to striatum reverses behavioral deficits induced by MPTP in primates: a comparison with other types of grafts as controls. Experimental Brain Research. 1991; 85(2):33548.

48. Widner H, Tetrud J, Rehncrona S, Snow B, Brundin P, Gustavii B, Bjorklund A, Lindvall O, Langston JW. Bilateral fetal mesencephalic grafting in two patients with parkinsonism induced by 1-methyl-4-phenyl-1,2,3,6-tetrahydropyridine (MPTP) [see comments]. New England Journal of Medicine. 1992; 327(22):1556-63. [PubMed: 1435882]

49. Kordower JH, Freeman TB, Snow BJ, Vingerhoets FJ, Mufson EJ, Sanberg PR, Hauser RA, Smith DA, Nauert GM, Perl DP, et al. Neuropathological evidence of graft survival and striatal reinnervation after the transplantation of fetal mesencephalic tissue in a patient with Parkinson's disease. N Engl J Med. 1995; 332(17):1118-24. [PubMed: 7700284]

50. Harrower TP, Tyers P, Hooks Y, Barker RA. Long-term survival and integration of porcine expanded neural precursor cell grafts in a rat model of Parkinson's disease. Exp Neurol. 2006; 197(1):56-69. [PubMed: 16246328]

51. Brevig T, Meyer M, Kristensen T, Zimmer J, Holgersson J. Xenotransplantation for brain repair: reduction of porcine donor tissue immunogenicity by treatment with anti-Gal antibodies and complement. Transplantation. 2001; 72(2):190-6. [PubMed: 11477337]

52. Frati G, Frati P, Muzzi L, Oricchio G, Papalia U, Yacoub MH. Medical and ethical issues in xenotransplantation: the opinion of the public, patients, and transplant candidates in Italy. Transplantation Proceedings. 2001; 33(1-2):1884-5. [PubMed: 11267553] 
53. Fink JS, Schumacher JM, Ellias SL, Palmer EP, Saint-Hilaire M, Shannon K, Penn R, Starr P, VanHorne C, Kott HS, Dempsey PK, Fischman AJ, Raineri R, Manhart C, Dinsmore J, Isacson O. Porcine xenografts in Parkinson's disease and Huntington's disease patients: preliminary results. Cell Transplant. 2000; 9(2):273-8. [PubMed: 10811399]

54. Barker RA, Kendall AL, Widner H. Neural tissue xenotransplantation: what is needed prior to clinical trials in Parkinson's disease? Neural Tissue Xenografting Project. Cell Transplant. 2000; 9(2):235-46. [PubMed: 10811396]

55. Schumacher JM, Isacson O. Neuronal xenotransplantation in Parkinson's disease. Nature Medicine. 1997; 3(5):474-5.

56. Deacon T, Schumacher J, Dinsmore J, Thomas C, Palmer P, Kott S, Edge A, Penney D, Kassissieh S, Dempsey P, Isacson O. Histological evidence of fetal pig neural cell survival after transplantation into a patient with Parkinson's disease. Nature Medicine. 1997; 3(3):350-3.

57. Galpern WR, Burns LH, Deacon TW, Dinsmore J, Isacson O. Xenotransplantation of porcine fetal ventral mesencephalon in a rat model of Parkinson's disease: functional recovery and graft morphology. Exp Neurol. 1996; 140(1):1-13. [PubMed: 8682173]

58. Isacson O, Deacon TW, Pakzaban P, Galpern WR, Dinsmore J, Burns LH. Transplanted xenogeneic neural cells in neurodegenerative disease models exhibit remarkable axonal target specificity and distinct growth patterns of glial and axonal fibres. Nature Medicine. 1995; 1(11): 1189-94.

59. Huffaker TK, Boss BD, Morgan AS, Neff NT, Strecker RE, Spence MS, Miao R. Xenografting of fetal pig ventral mesencephalon corrects motor asymmetry in the rat model of Parkinson's disease. Experimental Brain Research. 1989; 77(2):329-36.

60. Watts RL, Raiser CD, Stover NP, Cornfeldt ML, Schweikert AW, Subramanian T, Bakay RAE. Stereotaxic intrastriatal implantation of retinal pigment epithelial cells attached to microcarriers in advanced Parkinson disease patients: A pilot study. Neurology. 2001; 56(8 Supplement 3):A283.

61. Watts RL, Raiser CD, Stover NP, Cornfeldt ML, Schweikert AW, Allen RC, Subramanian T, Doudet D, Honey CR, Bakay RA. Stereotaxic intrastriatal implantation of human retinal pigment epithelial (hRPE) cells attached to gelatin microcarriers: a potential new cell therapy for Parkinson's disease. J Neural Transm Suppl. 2003; (65):215-27. [PubMed: 12946059]

62. Subramanian T, Marchionini D, Potter EM, Cornfeldt ML. Striatal xenotransplantation of human retinal pigment epithelial cells attached to microcarriers in hemiparkinsonian rats ameliorates behavioral deficits without provoking a host immune response. Cell Transplant. 2002; 11(3):20714. [PubMed: 12075986]

63. Stover NP, Watts RL. Spheramine for treatment of Parkinson's disease. Neurotherapeutics. 2008; 5(2):252-9. [PubMed: 18394567]

64. Stover NP, Bakay RA, Subramanian T, Raiser CD, Cornfeldt ML, Schweikert AW, Allen RC, Watts RL. Intrastriatal implantation of human retinal pigment epithelial cells attached to microcarriers in advanced Parkinson disease. Arch Neurol. 2005; 62(12):1833-7. [PubMed: 16344341]

65. Ming M, Li X, Fan X, Yang D, Li L, Chen S, Gu Q, Le W. Retinal pigment epithelial cells secrete neurotrophic factors and synthesize dopamine: possible contribution to therapeutic effects of RPE cell transplantation in Parkinson's disease. J Transl Med. 2009; 7:53. [PubMed: 19558709]

66. McKay BS, Goodman B, Falk T, Sherman SJ. Retinal pigment epithelial cell transplantation could provide trophic support in Parkinson's disease: results from an in vitro model system. Experimental Neurology. 2006; 201(1):234-43. [PubMed: 16764861]

67. Flores J, Cepeda IL, Cornfeldt ML, O’Kusky JR, Doudet DJ. Characterization and survival of long-term implants of human retinal pigment epithelial cells attached to gelatin microcarriers in a model of Parkinson disease. Journal of Neuropathology \& Experimental Neurology. 2007; 66(7): 585-96. [PubMed: 17620984]

68. Farag ES, Vinters HV, Bronstein J. Pathologic findings in retinal pigment epithelial cell implantation for Parkinson disease. Neurology. 2009

69. Falk T, Zhang S, Sherman SJ. Pigment epithelium derived factor (PEDF) is neuroprotective in two in vitro models of Parkinson's disease. Neurosci Lett. 2009; 458(2):49-52. [PubMed: 19442875] 
70. Doudet DJ, Cornfeldt ML, Honey CR, Schweikert AW, Allen RC. PET imaging of implanted human retinal pigment epithelial cells in the MPTP-induced primate model of Parkinson's disease. Experimental Neurology. 2004; 189(2):361-8. [PubMed: 15380486]

71. Cepeda IL, Flores J, Cornfeldt ML, O’Kusky JR, Doudet DJ. Human retinal pigment epithelial cell implants ameliorate motor deficits in two rat models of Parkinson disease. Journal of Neuropathology \& Experimental Neurology. 2007; 66(7):576-84. [PubMed: 17620983]

72. Roy NS, Cleren C, Singh SK, Yang L, Beal MF, Goldman SA. Functional engraftment of human ES cell-derived dopaminergic neurons enriched by coculture with telomerase-immortalized midbrain astrocytes.[see comment]. Nature Medicine. 2006; 12(11):1259-68.

73. Rodriguez-Gomez JA, Lu JQ, Velasco I, Rivera S, Zoghbi SS, Liow JS, Musachio JL, Chin FT, Toyama H, Seidel J, Green MV, Thanos PK, Ichise M, Pike VW, Innis RB, McKay RD. Persistent dopamine functions of neurons derived from embryonic stem cells in a rodent model of Parkinson disease. Stem Cells. 2007; 25(4):918-28. [PubMed: 17170065]

74. Kim JH, Auerbach JM, Rodriguez-Gomez JA, Velasco I, Gavin D, Lumelsky N, Lee SH, Nguyen J, Sanchez-Pernaute R, Bankiewicz K, McKay R. Dopamine neurons derived from embryonic stem cells function in an animal model of Parkinson's disease. Nature. 2002; 418(6893):50-6. [PubMed: 12077607]

75. Weick JP, Liu Y, Zhang SC. Human embryonic stem cell-derived neurons adopt and regulate the activity of an established neural network. Proc Natl Acad Sci U S A. 108(50):20189-94. [PubMed: 22106298]

76. Tonnesen J, Parish CL, Sorensen AT, Andersson A, Lundberg C, Deisseroth K, Arenas E, Lindvall $\mathrm{O}$, Kokaia M. Functional integration of grafted neural stem cell-derived dopaminergic neurons monitored by optogenetics in an in vitro Parkinson model. PLoS One. 6(3):e17560. [PubMed: 21394212]

77. Kriks S, Shim JW, Piao J, Ganat YM, Wakeman DR, Xie Z, Carrillo-Reid L, Auyeung G, Antonacci C, Buch A, Yang L, Beal MF, Surmeier DJ, Kordower JH, Tabar V, Studer L. Dopamine neurons derived from human ES cells efficiently engraft in animal models of Parkinson's disease. Nature. 2011; 480(7378):547-51. [PubMed: 22056989]

78. Wernig M, Zhao JP, Pruszak J, Hedlund E, Fu D, Soldner F, Broccoli V, Constantine-Paton M, Isacson O, Jaenisch R. Neurons derived from reprogrammed fibroblasts functionally integrate into the fetal brain and improve symptoms of rats with Parkinson's disease. Proceedings of the National Academy of Sciences of the United States of America. 2008; 105(15):5856-61. [PubMed: 18391196]

79. Yu J, Vodyanik MA, Smuga-Otto K, Antosiewicz-Bourget J, Frane JL, Tian S, Nie J, Jonsdottir GA, Ruotti V, Stewart R, Slukvin II, Thomson JA. Induced pluripotent stem cell lines derived from human somatic cells. Science. 2007; 318(5858):1917-20. [PubMed: 18029452]

80. Takahashi K, Tanabe K, Ohnuki M, Narita M, Ichisaka T, Tomoda K, Yamanaka S. Induction of pluripotent stem cells from adult human fibroblasts by defined factors. Cell. 2007; 131(5):861-72. [PubMed: 18035408]

81. Caiazzo M, Dell'Anno MT, Dvoretskova E, Lazarevic D, Taverna S, Leo D, Sotnikova TD, Menegon A, Roncaglia P, Colciago G, Russo G, Carninci P, Pezzoli G, Gainetdinov RR, Gustincich S, Dityatev A, Broccoli V. Direct generation of functional dopaminergic neurons from mouse and human fibroblasts. Nature. 476(7359):224-7. [PubMed: 21725324]

82. Cai J, Yang M, Poremsky E, Kidd S, Schneider JS, Iacovitti L. Dopaminergic neurons derived from human induced pluripotent stem cells survive and integrate into 6-OHDA-lesioned rats. Stem Cells Dev. 2009; 19(7):1017-23. [PubMed: 19824823]

83. Backlund EO, Granberg PO, Hamberger B, Knutsson E, Martensson A, Sedvall G, Seiger A, Olson L. Transplantation of adrenal medullary tissue to striatum in parkinsonism. First clinical trials. J Neurosurg. 1985; 62(2):169-73. [PubMed: 2578558]

84. Diamond SG, Markham CH, Rand RW, Becker DP, Treciokas LJ. Four-year follow-up of adrenalto-brain transplants in Parkinson's disease. Archives of Neurology. 1994; 51(6):559-63. [PubMed: 8198466]

85. Gash DM, Collier TJ, Sladek JR Jr. Neural transplantation: a review of recent developments and potential applications to the aged brain. Neurobiology of Aging. 1985; 6(2):131-74. [PubMed: 3895013] 
86. Madrazo I, Franco BR, Aguilera M, Ostrosky SF, Madrazo M, Cuevas C, Catrejon H, Guizar ZG, Magallon E. Autologous adrenal medullary, fetal mesencephalic, and fetal adrenal brain transplantation in Parkinson's disease: a long-term postoperative follow-up. J Neural Transplant Plast. 1991; 2(3-4):157-64. [PubMed: 1782251]

87. Nicoleau C, Viegas P, Peschanski M, Perrier AL. Human pluripotent stem cell therapy for Huntington's disease: technical, immunological, and safety challenges human pluripotent stem cell therapy for Huntington's disease: technical, immunological, and safety challenges. Neurotherapeutics. 8(4):562-76. [PubMed: 21976138]

88. Chambers SM, Fasano CA, Papapetrou EP, Tomishima M, Sadelain M, Studer L. Highly efficient neural conversion of human ES and iPS cells by dual inhibition of SMAD signaling. Nat Biotechnol. 2009; 27(3):275-80. [PubMed: 19252484]

89. Foulds PG, Mitchell JD, Parker A, Turner R, Green G, Diggle P, Hasegawa M, Taylor M, Mann D, Allsop D. Phosphorylated alpha-synuclein can be detected in blood plasma and is potentially a useful biomarker for Parkinson's disease. FASEB J. 2011; 25(12):4127-37. [PubMed: 21865317]

90. Braak H, Del Tredici K, Rub U, de Vos RA, Jansen Steur EN, Braak E. Staging of brain pathology related to sporadic Parkinson's disease. Neurobiol Aging. 2003; 24(2):197-211. [PubMed: 12498954]

91. Subramanian T. Cell transplantation for the treatment of Parkinson's disease. Semin Neurol. 2001; 21(1):103-15. [PubMed: 11346020]

92. Freed CR, Breeze RE, Rosenberg NL, Schneck SA, Kriek E, Qi JX, Lone T, Zhang YB, Snyder JA, Wells TH. Survival of implanted fetal dopamine cells and neurologic improvement 12 to 46 months after transplantation for Parkinson's disease [see comments]. New England Journal of Medicine. 1992; 327(22):1549-55. [PubMed: 1435881]

93. Hauser RA, Freeman TB, Snow BJ, Nauert M, Gauger L, Kordower JH, Olanow CW. Long-term evaluation of bilateral fetal nigral transplantation in Parkinson disease. Archives of Neurology. 1999; 56(2):179-87. [PubMed: 10025423]

94. Hagell P, Piccini P, Bjorklund A, Brundin P, Rehncrona S, Widner H, Crabb L, Pavese N, Oertel WH, Quinn N, Brooks DJ, Lindvall O. Dyskinesias following neural transplantation in Parkinson's disease. Nat Neurosci. 2002; 5(7):627-8. [PubMed: 12042822]

95. Hagell P, Cenci MA. Dyskinesias and dopamine cell replacement in Parkinson's disease: a clinical perspective. Brain Research Bulletin. 2005; 68(1-2):4-15. [PubMed: 16324999]

96. Lindvall O, Bjorklund A. Cell replacement therapy: helping the brain to repair itself. NeuroRx. 2004; 1(4):379-81. [PubMed: 15717041]

97. McGeer PL, Yasojima K, McGeer EG. Inflammation in Parkinson's disease. Adv Neurol. 2001; 86:83-9. [PubMed: 11554012]

98. McGeer EG, McGeer PL. The role of the immune system in neurodegenerative disorders. Mov Disord. 1997; 12(6):855-8. [PubMed: 9399206]

99. Steece-Collier K, Rademacher DJ, Soderstrom K. Anatomy of graft-induced dyskinesias: Circuit remodeling in the parkinsonian striatum. Basal ganglia. 2012

100. Arai R, Karasawa N, Geffard M, Nagatsu I. L-DOPA is converted to dopamine in serotonergic fibers of the striatum of the rat: a double-labeling immunofluorescence study. Neurosci Lett. 1995; 195(3):195-8. [PubMed: 8584208]

101. Ahlskog JE, Muenter MD. Frequency of levodopa-related dyskinesias and motor fluctuations as estimated from the cumulative literature. Mov Disord. 2001; 16(3):448-58. [PubMed: 11391738]

102. Carta M, Carlsson T, Munoz A, Kirik D, Bjorklund A. Role of serotonin neurons in the induction of levodopa- and graft-induced dyskinesias in Parkinson's disease. Mov Disord. 25(Suppl 1):S174-9. [PubMed: 20187238]

103. Carlsson T, Carta M, Winkler C, Bjorklund A, Kirik D. Serotonin neuron transplants exacerbate L-DOPA-induced dyskinesias in a rat model of Parkinson's disease. J Neurosci. 2007; 27(30): 8011-22. [PubMed: 17652591]

104. Munoz A, Li Q, Gardoni F, Marcello E, Qin C, Carlsson T, Kirik D, Di Luca M, Bjorklund A, Bezard E, Carta M. Combined 5-HT1A and 5-HT1B receptor agonists for the treatment of LDOPA-induced dyskinesia. Brain. 2008; 131(Pt 12):3380-94. [PubMed: 18952677] 
105. Tanaka H, Kannari K, Maeda T, Tomiyama M, Suda T, Matsunaga M. Role of serotonergic neurons in L-DOPA-derived extracellular dopamine in the striatum of 6-OHDA-lesioned rats. Neuroreport. 1999; 10(3):631-4. [PubMed: 10208602]

106. Kannari K, Tanaka H, Maeda T, Tomiyama M, Suda T, Matsunaga M. Reserpine pretreatment prevents increases in extracellular striatal dopamine following L-DOPA administration in rats with nigrostriatal denervation. J Neurochem. 2000; 74(1):263-9. [PubMed: 10617128]

107. Carta M, Carlsson T, Kirik D, Bjorklund A. Dopamine released from 5-HT terminals is the cause of L-DOPA-induced dyskinesia in parkinsonian rats. Brain. 2007; 130(Pt 7):1819-33. [PubMed: 17452372]

108. Subramanian, T.; Deogaonkar, M. Cell transplantation and gene therapy for the treatment of Parkinson's disease. In: Galvez-Jimenez, N., editor. Scientific basis for the treatment of Parkinson's disease. Taylor \& Francis Medical Books; London: 2005. p. 233-250.

109. Horie S, Sugita S, Futagami Y, Yamada Y, Mochizuki M. Human retinal pigment epitheliuminduced CD4+CD25+ regulatory T cells suppress activation of intraocular effector T cells. Clin Immunol. 2010; 136(1):83-95. [PubMed: 20350837]

110. Sugita S. Role of ocular pigment epithelial cells in immune privilege. Arch Immunol Ther Exp (Warsz). 2009; 57(4):263-8. [PubMed: 19568919]

111. Sugita S, Horie S, Yamada Y, Mochizuki M. Inhibition of B cell activation by retinal pigment epithelium. Invest Ophthalmol Vis Sci. 2010

112. Zamiri P, Sugita S, Streilein JW. Immunosuppressive properties of the pigmented epithelial cells and the subretinal space. Chemical Immunology \& Allergy. 2007; 92:86-93. [PubMed: 17264485]

113. Gross RE, Watts RL, Hauser RA, Bakay RA, Reichmann H, von Kummer R, Ondo WG, Reissig E, Eisner W, Steiner-Schulze H, Siedentop H, Fichte K, Hong W, Cornfeldt M, Beebe K, Sandbrink R. Intrastriatal transplantation of microcarrier-bound human retinal pigment epithelial cells versus sham surgery in patients with advanced Parkinson's disease: a double-blind, randomised, controlled trial. Lancet Neurol. 2011; 10(6):509-19. [PubMed: 21565557]

114. Mendez I, Sanchez-Pernaute R, Cooper O, Vinuela A, Ferrari D, Bjorklund L, Dagher A, Isacson O. Cell type analysis of functional fetal dopamine cell suspension transplants in the striatum and substantia nigra of patients with Parkinson's disease. Brain. 2005; 128(Pt 7):1498-510. [PubMed: 15872020]

115. Raivich G, Banati R. Brain microglia and blood-derived macrophages: molecular profiles and functional roles in multiple sclerosis and animal models of autoimmune demyelinating disease. Brain Research - Brain Research Reviews. 2004; 46(3):261-81. [PubMed: 15571769]

116. Biju K, Zhou Q, Li G, Imam SZ, Roberts JL, Morgan WW, Clark RA, Li S. Macrophagemediated GDNF delivery protects against dopaminergic neurodegeneration: a therapeutic strategy for Parkinson's disease. Mol Ther. 2010; 18(8):1536-44. [PubMed: 20531393]

117. Subramanian T, Pollack IF, Lund RD. Rejection of mesencephalic retinal xenografts in the rat induced by systemic administration of recombinant interferon-gamma. Exp Neurol. 1995; 131(1): 157-62. [PubMed: 7895809]

118. Borlongan CV, Stahl CE, Cameron DF, Saporta S, Freeman TB, Cahill DW, Sanberg PR. CNS immunological modulation of neural graft rejection and survival. Neurol Res. 1996; 18(4):297304. [PubMed: 8875445]

119. Brundin P, Strecker RE, Widner H, Clarke DJ, Nilsson OG, Astedt B, Lindvall O, Bjorklund A. Human fetal dopamine neurons grafted in a rat model of Parkinson's disease: immunological aspects, spontaneous and drug-induced behaviour, and dopamine release. Experimental Brain Research. 1988; 70(1):192-208.

120. Lund RD, Rao K, Hankin MH, Kunz HW, Gill TJ 3rd. Transplantation of retina and visual cortex to rat brains of different ages. Maturation, connection patterns, and immunological consequences. Annals of the New York Academy of Sciences. 1987; 495:227-41. [PubMed: 3474943]

121. Kumar, V.; Abbas, AK.; Fausto, N.; Aster, J. Robbins and Cotran Pathologic Basis of Disease. 8th edition. 2010.

122. Sugino IK, Sun Q, Wang J, Nunes CF, Cheewatrakoolpong N, Rapista A, Johnson AC, Malcuit C, Klimanskaya I, Lanza R, Zarbin MA. Comparison of FRPE and human embryonic stem cell- 
derived RPE behavior on aged human Bruch's membrane. Invest Ophthalmol Vis Sci. 52(8): 4979-97. [PubMed: 21460262]

123. Kannan R, Sreekumar PG, Hinton DR. VEGF and PEDF secretion in ARPE-19 and fhRPE cells. Invest Ophthalmol Vis Sci. 52(12):9047. [PubMed: 22104197]

124. Kordower JH, Dodiya HB, Kordower AM, Terpstra B, Paumier K, Madhavan L, Sortwell C, Steece-Collier K, Collier TJ. Transfer of host-derived alpha synuclein to grafted dopaminergic neurons in rat. Neurobiol Dis. 2011; 43(3):552-7. [PubMed: 21600984]

125. Roy NS, Cleren C, Singh SK, Yang L, Beal MF, Goldman SA. Functional engraftment of human ES cell-derived dopaminergic neurons enriched by coculture with telomerase-immortalized midbrain astrocytes. Nat Med. 2006; 12(11):1259-68. [PubMed: 17057709]

126. Barcia C, Ros CM, Annese V, Gomez A, Ros-Bernal F, Aguado-Yera D, Martinez-Pagan ME, de Pablos V, Fernandez-Villalba E, Herrero MT. IFN-gamma signaling, with the synergistic contribution of TNF-alpha, mediates cell specific microglial and astroglial activation in experimental models of Parkinson's disease. Cell Death Dis. 2:e142. [PubMed: 21472005]

127. Chakrabarty P, Ceballos-Diaz C, Lin WL, Beccard A, Jansen-West K, McFarland NR, Janus C, Dickson D, Das P, Golde TE. Interferon-gamma induces progressive nigrostriatal degeneration and basal ganglia calcification. Nat Neurosci. 14(6):694-6. [PubMed: 21572432]

128. Bongioanni P, Mondino C, Borgna M, Boccardi B, Sposito R, Castagna M. T-lymphocyte immuno-interferon binding in parkinsonian patients. J Neural Transm. 1997; 104(2-3):199-207. [PubMed: 9203082]

129. Chen X, Ghribi O, Geiger JD. Caffeine protects against disruptions of the blood-brain barrier in animal models of Alzheimer's and Parkinson's diseases. J Alzheimers Dis. 20(Suppl 1):S127-41. [PubMed: 20164568]

130. Grammas P, Martinez J, Miller B. Cerebral microvascular endothelium and the pathogenesis of neurodegenerative diseases. Expert Rev Mol Med. 13:e19. [PubMed: 21676288]

131. Rajabally YA, Martey J. Neuropathy in Parkinson disease: prevalence and determinants. Neurology. 77(22):1947-50. [PubMed: 22049200]

132. Lund RD, Rao K, Hankin MH, Kunz HW, Gill TJ 3rd. Immunogenetic aspects of neural transplantation. Transplantation Proceedings. 1987; 19(1 Pt 2):1128-9. [PubMed: 3274292]

133. Young MJ, Rao K, Lund RD. Integrity of the blood-brain barrier in retinal xenografts is correlated with the immunological status of the host. Journal of Comparative Neurology. 1989; 283(1):107-17. [PubMed: 2732354]

134. Carder RK, Snyder-Keller AM, Lund RD. Behavioral and anatomical correlates of immunologically induced rejection of nigral xenografts. Journal of Comparative Neurology. 1988; 277(3):391-402. [PubMed: 2904453]

135. Backes MG, Lund RD, Lagenaur CF, Kunz HW, Gill TJ 3rd. Cellular events associated with peripherally induced rejection of mature neural xenografts placed into neonatal rat brains. $\mathrm{J}$ Comp Neurol. 1990; 295(3):428-37. [PubMed: 2351761]

136. Pollack IF, Lund RD, Rao K. MHC antigen expression and cellular response in spontaneous and induced rejection of intracerebral neural xenografts in neonatal rats. Restor Neurol Neurosci. 1990; 1(5):347-60. [PubMed: 21551577]

137. Subramanian T, Pollack IF, Lund RD. The Effect of Cyclosporine a on Eye Removal-Induced Rejection of Mesencephalic Retinal Xenografts. Society for Neuroscience Abstracts. 1991; 17(1-2):1137.

138. Larsson LC, Duan WM, Widner H. Discordant xenografts: different outcome after mouse and rat neural tissue transplantation to guinea-pigs. Brain Res Bull. 1999; 49(5):367-76. [PubMed: 10452358]

139. Duan WM, Westerman MA, Wong G, Low WC. Rat nigral xenografts survive in the brain of MHC class II-, but not class I-deficient mice. Neuroscience. 2002; 115(2):495-504. [PubMed: 12421616]

140. Duan WM, Widner H, Frodl EM, Brundin P. Immune reactions following systemic immunization prior or subsequent to intrastriatal transplantation of allogeneic mesencephalic tissue in adult rats. Neuroscience. 1995; 64(3):629-41. [PubMed: 7715776] 
141. Duan WM, Brundin P, Widner H. Addition of allogeneic spleen cells causes rejection of intrastriatal embryonic mesencephalic allografts in the rat. Neuroscience. 1997; 77(2):599-609. [PubMed: 9472415]

142. Duan WM, Westerman M, Flores T, Low WC. Survival of intrastriatal xenografts of ventral mesencephalic dopamine neurons from MHC-deficient mice to adult rats. Experimental Neurology. 2001; 167(1):108-17. [PubMed: 11161598]

143. Duan WM, Brundin P, Grasbon-Frodl EM, Widner H. Methylprednisolone prevents rejection of intrastriatal grafts of xenogeneic embryonic neural tissue in adult rats. Brain Res. 1996; 712(2): 199-212. [PubMed: 8814894]

144. Brundin P, Nilsson OG, Gage FH, Bjorklund A. Cyclosporin A increases survival of crossspecies intrastriatal grafts of embryonic dopamine-containing neurons. Exp Brain Res. 1985; 60(1):204-8. [PubMed: 3930278]

145. Elsworth JD, Brittan MS, Taylor JR, Sladek JR Jr. al-Tikriti MS, Zea-Ponce Y, Innis RB, Redmond DE Jr. Roth RH. Restoration of dopamine transporter density in the striatum of fetal ventral mesencephalon-grafted, but not sham-grafted, MPTP-treated parkinsonian monkeys. Cell Transplantation. 1996; 5(2):315-25. [PubMed: 8689042]

146. Redmond DE Jr. Vinuela A, Kordower JH, Isacson O. Influence of cell preparation and target location on the behavioral recovery after striatal transplantation of fetal dopaminergic neurons in a primate model of Parkinson's disease. Neurobiol Dis. 2008; 29(1):103-16. [PubMed: 17920901]

147. Sladek JR Jr. Collier TJ, Haber SN, Deutch AY, Elsworth JD, Roth RH, Redmond DE Jr. Reversal of parkinsonism by fetal nerve cell transplants in primate brain. Annals of the New York Academy of Sciences. 1987; 495:641-57. [PubMed: 2886092]

148. Bakay RA, Boyer KL, Freed CR, Ansari AA. Immunological responses to injury and grafting in the central nervous system of nonhuman primates. Cell Transplantation. 1998; 7(2):109-20. [PubMed: 9588593]

149. Fiandaca MS, Bakay RA, Sweeney KM, Chan WC. Immunologic response to intracerebral fetal neural allografts in the rhesus monkey. Prog Brain Res. 1988; 78:287-96. [PubMed: 3247431]

150. Bakay RA, Barrow DL, Fiandaca MS, Iuvone PM, Schiff A, Collins DC. Biochemical and behavioral correction of MPTP Parkinson-like syndrome by fetal cell transplantation. Ann N Y Acad Sci. 1987; 495:623-40. [PubMed: 3496821]

151. Bakay RA, King FA. Transplanted fetal monkey neurons. Lancet. 1986; 2(8499):163. [PubMed: 2873425]

152. Bakay RA, Fiandaca MS, Barrow DL, Schiff A, Collins DC. Preliminary report on the use of fetal tissue transplantation to correct MPTP-induced Parkinson-like syndrome in primates. Appl Neurophysiol. 1985; 48(1-6):358-61. [PubMed: 3879797]

153. Jacoby DB, Lindberg C, Ratliff J, Wetzel K, Stewart GR, Dinsmore J. Comparison of fresh and cryopreserved porcine ventral mesencephalon cells transplanted in A rat model of Parkinson's disease. J Neurosci Res. 2002; 69(3):382-96. [PubMed: 12125079]

154. Schumacher JM, Ellias SA, Palmer EP, Kott HS, Dinsmore J, Dempsey PK, Fischman AJ, Thomas C, Feldman RG, Kassissieh S, Raineri R, Manhart C, Penney D, Fink JS, Isacson O. Transplantation of embryonic porcine mesencephalic tissue in patients with PD. Neurology. 2000; 54(5):1042-50. [PubMed: 10720272]

155. Freed CR, Breeze RE, Rosenberg NL, Schneck SA, Kriek E, Qi JX, Lone T, Zhang YB, Snyder JA, Wells TH, et al. Survival of implanted fetal dopamine cells and neurologic improvement 12 to 46 months after transplantation for Parkinson's disease. N Engl J Med. 1992; 327(22):1549_ 55. [PubMed: 1435881]

156. Alemdar AY, Sadi D, McAlister V, Mendez I. Intracerebral co-transplantation of liposomal tacrolimus improves xenograft survival and reduces graft rejection in the hemiparkinsonian rat. Neuroscience. 2007; 146(1):213-24. [PubMed: 17303340]

157. Honey CR, Obochi MO, Shen H, Margaron P, Yip S, Levy JG. Reduced xenograft rejection in rat striatum after pretransplant photodynamic therapy of murine neural xenografts. J Neurosurg. 2000; 92(1):127-31. [PubMed: 10616091] 
158. Saporta S, Borlongan C, Moore J, Mejia-Millan E, Jones SL, Bonness P, Randall TS, Allen RC, Freeman TB, Sanberg PR. Microcarrier enhanced survival of human and rat fetal ventral mesencephalon cells implanted in the rat striatum. Cell Transplant. 1997; 6(6):579-84. [PubMed: 9440867]

159. Sanberg PR, Borlongan CV, Saporta S, Cameron DF. Testis-derived Sertoli cells survive and provide localized immunoprotection for xenografts in rat brain. Nat Biotechnol. 1996; 14(13): 1692-5. [PubMed: 9634853]

160. Cameron DF, Hushen JJ, Colina L, Mallery J, Willing A, Sanberg PR, Saporta S. Formation and structure of transplantable tissue constructs generated in simulated microgravity from Sertoli cells and neuron precursors. Cell Transplant. 2004; 13(7-8):755-63. [PubMed: 15690977]

161. Emerich DF, Hemendinger R, Halberstadt CR. The testicular-derived Sertoli cell: cellular immunoscience to enable transplantation. Cell Transplant. 2003; 12(4):335-49. [PubMed: 12911122]

162. Alemdar AY, Sadi D, McAlister VC, Mendez I. Liposomal formulations of tacrolimus and rapamycin increase graft survival and fiber outgrowth of dopaminergic grafts. Cell Transplant. 2004; 13(3):263-71. [PubMed: 15191164] 


\section{Highlights}

- Cografting of immunomodulatory cells can alter host microenvironment and provide trophic support.

- Graft mediated immunosuppression may improve graft survival and prevent teratoma formation.

- Cograft mediated immunomodulation could avoid the adverse effects of systemic immunosuppression. 


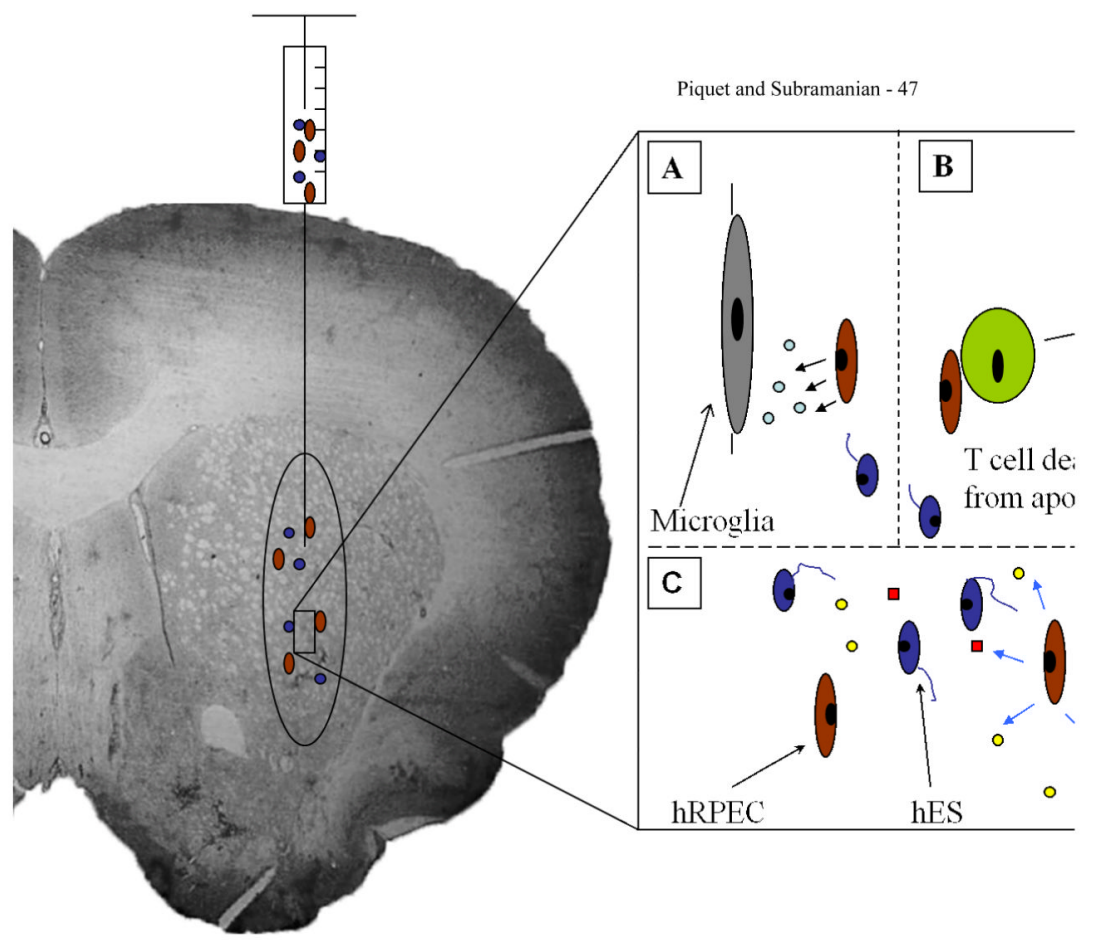

Figure 1. Schematic diagram of a grafting scenario of hRPEC cografted with hES grafts This diagram depicts hRPEC cografted with hES using stereotactic injection of cell suspension into the striatum. Enlarged schematic of cograft shows possible mechanisms of hRPEC (brown ovoid cells) providing localized immunosuppressed microenvironment that prevent deleterious host immune responses and promote growth and differentiation of hES (blue cells with neurite extensions). A. Possible role of hRPEC secreting immune modulating factors, thus suppressing microglial activation. B. hRPECs inducing apoptosis of cytotoxic T cells, thus decreasing the host cell mediated immune response. C. hRPECs could possibly provide various growth factors (yellow circles and red squares) to promote the growth and differentiation of the hES cells and to provide anti-teratoma effects. 
TABLE 1

Summary of Transplantation Approaches

\begin{tabular}{|l|l|l|}
\hline $\begin{array}{l}\text { Transplantation } \\
\text { Approaches: }\end{array}$ & Outcomes: & $\begin{array}{l}\text { Representative } \\
\text { References }\end{array}$ \\
\hline $\begin{array}{l}\text { Adrenal Medulla } \\
\text { Transplants }\end{array}$ & Cell survival poor, failed in blinded clinical trials & {$[27-30]$} \\
\hline Carotid Body Grafts & Minimal benefits in clinical trials & {$[31-37]$} \\
\hline $\begin{array}{l}\text { Allogenic Human FVM } \\
\text { Transplants }\end{array}$ & $\begin{array}{l}\text { Ethical concerns, failed in clinical trials despite several } \\
\text { spectacular successes reported in open-label studies from } \\
\text { several different centers, Lewy body like pathology in grafts, } \\
\text { graft-induced dyskinesias in many patients }\end{array}$ & {$[38-49]$} \\
\hline $\begin{array}{l}\text { Porcine FVM } \\
\text { Xenotransplants }\end{array}$ & $\begin{array}{l}\text { Need chronic immunosuppression, failed in clinical trial } \\
\text { despite success in preclinical studies }\end{array}$ & {$[50-59]$} \\
\hline hRPEC transplants & $\begin{array}{l}\text { Post-natal hRPEC failed in placebo controlled clinical trials, } \\
\text { but embryonic hRPEC were successfully engrafted in animal } \\
\text { studies and effective in open-labeled clinical trials. No need } \\
\text { for immunosuppression even in the case of embryonic } \\
\text { hRPEC xenografts. However, limited autopsy report from } \\
\text { post-natal hRPEC grafted patent showed poor cell survival } \\
\text { and macrophage infiltration of graft sites. }\end{array}$ & {$[60-71]$} \\
\hline hES Transplant & $\begin{array}{l}\text { No clinical trial yet, cell death of transplanted cells reported } \\
\text { even with immunosuppression }\end{array}$ & {$[72-77]$} \\
\hline iPSC Transplant & $\begin{array}{l}\text { No clinical trial yet, immunosuppression necessary to avoid } \\
\text { cell death in grafts }\end{array}$ & {$[17,78-82]$} \\
\hline
\end{tabular}




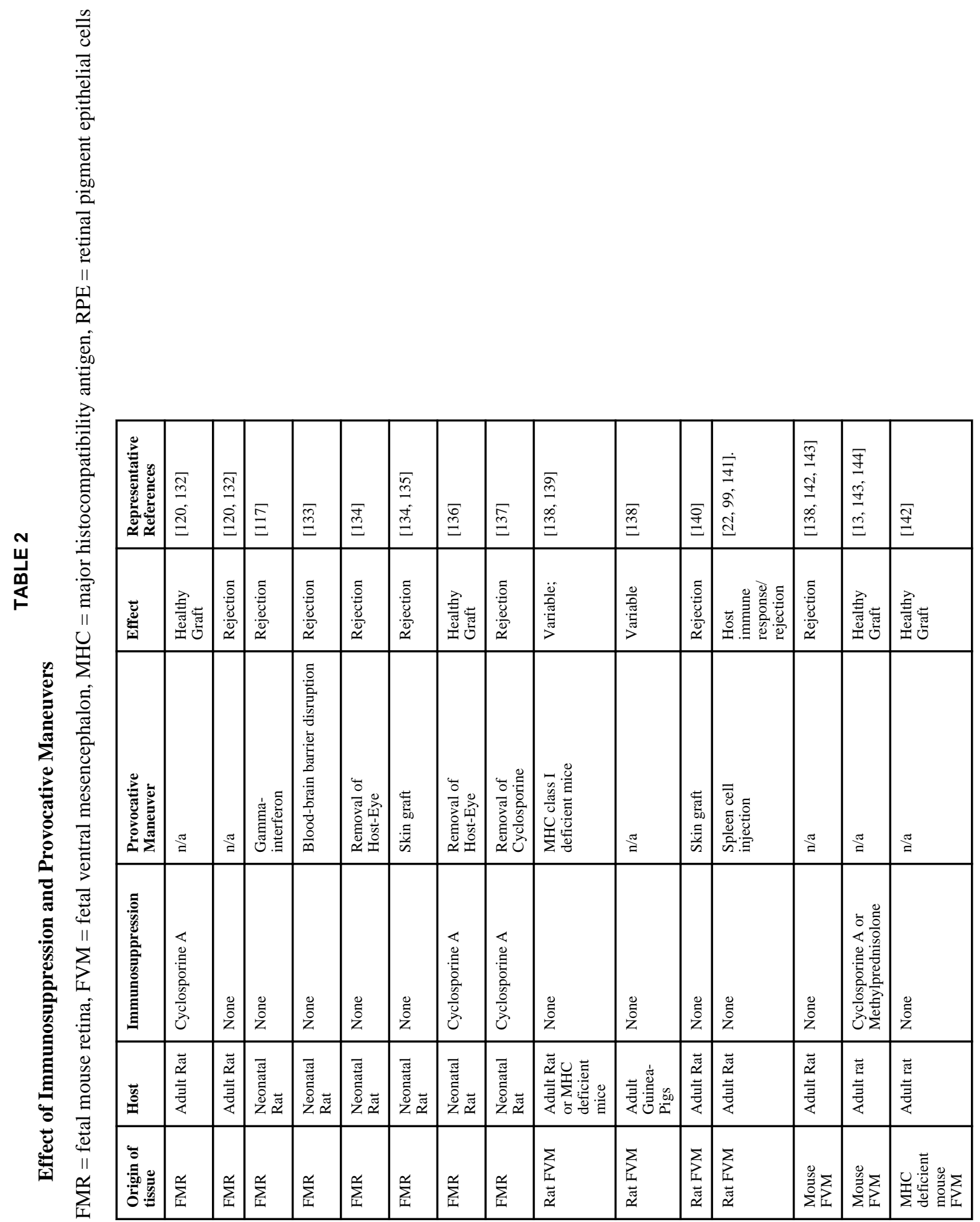




\begin{tabular}{|c|c|c|c|c|c|c|c|c|c|c|c|}
\hline 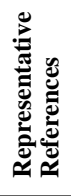 & $\stackrel{\infty}{\stackrel{\infty}{⿹}}$ & 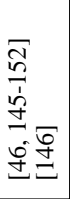 & $\sqrt{\sqrt{n}}$ & $\stackrel{\bar{n}}{\varrho}$ & 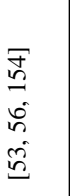 & $\begin{array}{l}\bar{n} \\
\text { a } \\
\text { ma } \\
\dot{a} \\
\dot{q} \\
\dot{q}\end{array}$ & 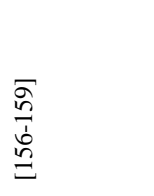 & $\overline{\widetilde{\sigma}}$ & $\overline{\underline{\sigma}}$ & $\begin{array}{l}\text { E } \\
\text { తి }\end{array}$ & $\begin{array}{l}\stackrel{\bar{g}}{=} \\
\stackrel{0}{0}\end{array}$ \\
\hline 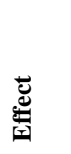 & 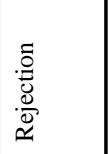 & 苞焉 & 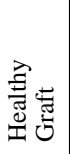 & 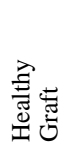 & $\begin{array}{l}\frac{0}{0} \\
\frac{\pi}{5} \\
\frac{\pi}{5}\end{array}$ & 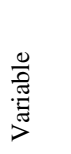 & 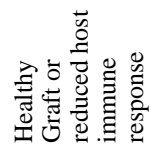 & 蒗 & 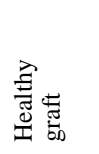 & 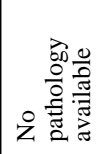 & 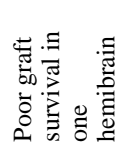 \\
\hline 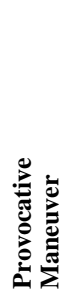 & 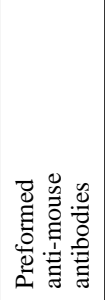 & $\stackrel{\pi}{\Xi}$ & $\Xi$ & $\Xi$ & 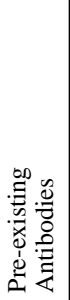 & $\Xi$ & $\stackrel{\Xi}{\Xi}$ & $\Xi$ & $\Xi$ & $\stackrel{\Xi}{\nexists}$ & $\stackrel{\pi}{\rightleftarrows}$ \\
\hline 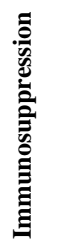 & 气̆ & 气̆ & 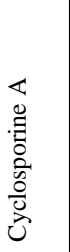 & 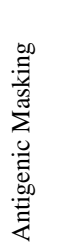 & 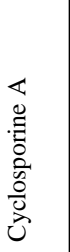 & 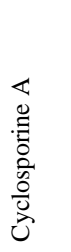 & 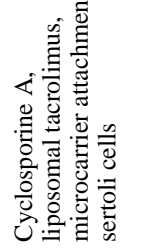 & 荾 & 号 & 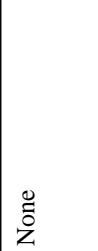 & 䒓 \\
\hline 蒙 & 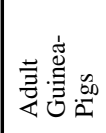 & $\frac{\vec{d}}{\sum_{\overline{2}}^{\circ}}$ & 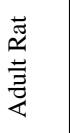 & 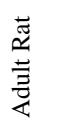 & 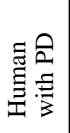 & $\begin{array}{l}\text { 急全 } \\
\text { 言言 }\end{array}$ & 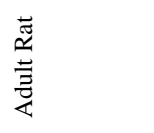 & 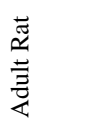 & 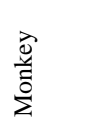 & $\begin{array}{l}\text { 产全 } \\
\text { 言言 }\end{array}$ & 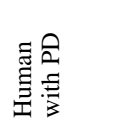 \\
\hline 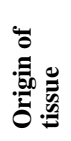 & 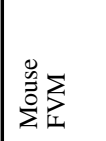 & 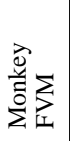 & 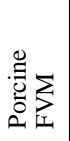 & 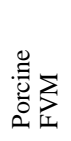 & 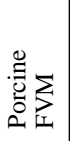 & 吾 & 茎焉 & 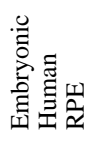 & 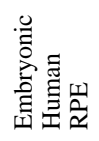 & 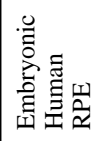 & 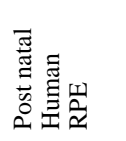 \\
\hline
\end{tabular}

